\title{
Vitamin D supplementation as a control program against latent tuberculosis infection in Korean high school students
}

\author{
Eun Hee Kim, Jong-Myon Bae \\ Department of Preventive Medicine, Jeju National University School of Medicine, Jeju, Korea
}

The prevalence of latnet Mycobacterium tuberculosis infection (LTBI) in the first-grade high school students in South Korea was $2.1 \%$, which was the lowest level at congregated settings in 2017. For LTBI cases refusing anti-tuberculosis (TB) medication or having poor compliance, additional support should be considered. Eight systematic reviews concluded that vitamin D (VD) deficiency is a risk factor for TB. While three of four South Korean adolescents were VD deficiency, VD supplementation could be a practical remedy to protect LTBI students of refusing anti-TB medication or having poor compliance.

KEY WORDS: Latent tuberculosis, Disease management, Vitamin D, Antitubercular agents, Prevention and control

\section{INTRODUCTION}

In order to reduce the incidence of tuberculosis (TB) in the country, the Korea Centers for Disease Control and Prevention (KCDC) launched a project in 2017 to administer prophylactic anti-TB drugs to persons who had tested positive for latent Mycobacterium tuberculosis infection (LTBI) [1]. However, because first-grade high school students among the target groups as selected by the Korean government are not covered in the World Health Organization guidelines on the management of LTBI published in 2015 [2], it has been pointed out that there is a lack of medical basis for selection of the project target groups [3].

Nevertheless, the KCDC conducted the project in 2017 and announced its results showing that the prevalence rate of LTBI among all the subjects was $11.6 \%$, and the prevalence of LTBI among firstgrade high school students was the lowest $(2.1 \%)$ among the pro-

\section{Correspondence: Jong-Myon Bae}

Department of Preventive Medicine, Jeju National University School of Medicine, 102 Jejudaehak-ro, Jeju 63243, Korea

E-mail:jmbae@jejunu.ac.kr

Received: Apr 25, 2018 / Accepted: Jul 25, 2018 / Published: Jul 27, 2018

This article is available from: http://e-epih.org/

(C) This is an open-access article distributed under the terms of the Creative Commons Attribution License (http://creativecommons.org/licenses/by/4.0/), which permits unrestricted use, distribution, and reproduction in any medium, provided the original work is properly cited.

(C) 2018, Korean Society of Epidemiology ject target groups [4]. Although no information on how many of the LTBI-positive subjects had received anti-TB drugs is available in that article, the medication acceptance and compliance rates are expected to be low considering the public opinion regarding the adverse effects of anti-TB drugs [5]. Therefore, it can be inferred that the prophylactic effects of the LTBI screening project against the entire related project cost was the lowest for the first-grade students among the target groups. Therefore, it was concluded that there was little evidence to support a national-scale LTBI screening project for first-grade high school students in South Korea (hereafter Korea).

Meanwhile, the KCDC has no consideration on follow-up measures for LTBI-positive students who refused anti-TB medication. It should also be considered that this can cause unnecessary emotional pressure on the students and their parents. Therefore, this manuscript aimed to seek ways to prevent the progression of LTBI to active TB in LTBI-positive patients refusing to take anti-TB drugs.

\section{MAIN BODY}

Mycobacterium tuberculosis (MTB), upon entry into the human body, is lysed in phagosomes inside macrophages, and if the concentration of intracellular $\mathrm{Ca}^{2+}$ ions does not increase, the MTB resides in the phagosomes are not lysed, thereby leading to LTBI [6]. Thus, vitamin D (VD), which is involved in calcium metabolism, is directly or indirectly involved in human immunity $[7,8]$. In this regard, there has been accumulating evidence that VD de- 
Table 1. Main conclusions of systematic reviews associated with VD level and activation of TB

\begin{tabular}{lcl}
\hline First author (year) [Ref] & $\begin{array}{c}\text { No. of selected } \\
\text { articles }\end{array}$ & Main conclusions \\
\hline Huang (2016) [14] & 38 & VD deficiency is a risk factor for TB \\
Wallis (2016) [15] & 8 & VD is thought to have anti-inflammatory effects \\
Keflie (2015) [16] & 23 & $88.9 \%$ of TB patients had VD deficiency \\
Zeng (2015) [17] & 15 & VD level less than 25 nmol/L was significantly associated with an increased risk of TB \\
Sutaria (2014) [18] & 7 & TB patients have lower VD status; Supplementation with VD leads to improved clinical outcomes \\
Nnoaham (2008) [19] & 7 & Low serum VD levels are associated with high risk of active TB \\
Xia (2014) [20] & 5 & VD supplementation have not any beneficial effect in TB treatment \\
Yamshchikov (2009) [21] & 13 & Serious adverse events attributable to VD supplementation were rare \\
\hline
\end{tabular}

VD, vitamin D; TB, tuberculosis; Ref, reference number.

ficiency is a risk factor for TB infection $[9,10]$.

Prior to the development of anti-TB drugs, cod liver oil, sunbathing, and oral/injectable VD supplementation had been used to treat active TB [11]. In addition, the epidemiological phenomena showing seasonal variation in the occurrence of TB throughout the year are interpreted to be related to VD deficiency due to the difference in the amount of sunshine [12,13].

As of the end of December 2017, eight systematic reviews regarding the association between TB and VD had been published (Table 1). The main results are summarized as follows: First, VD levels were significantly lower in patients with $\mathrm{TB}$, and, thus, VD deficiency could be a risk factor for TB [14-19]. Second, the administration of VD supplements is not beneficial in the treatment of active TB [20]. Third, VD supplements are safe [21].

However, there has been no systematic review on the hypothesis that VD supplements may prevent the activation of latent $\mathrm{TB}$. This is because of a lack of relevant studies. According to the results reported so far, VD levels were significantly lower in patients with LTBI than that in healthy persons [22], anti-TB immunity was strengthened in a general population who received VD, compared to those who received placebo [23], and the conversion rate of the tuberculin skin test was lower among school children taking VD, while their heights increased [24]. Based on these findings, we can hypothesize that VD may inhibit progression from LTBI to active TB $[12,25]$.

\section{CONCLUSION AND SUGGESTIONS}

Based on the results of the previous studies, it is concluded that VD is involved in the progression from an initial infection with TB to latent TB and active TB [8]. Therefore, it can be also inferred that the administration of VD supplements can inhibit the development of TB [14].

Meanwhile, according to data from the Korea National Health and Nutrition Examination Survey, 73.3\% of Korean adolescents were in a state of VD deficiency $(<20 \mathrm{ng} / \mathrm{mL})$ [26], and about $90 \%$ of Korean adolescents had a VD level of less than $10 \mathrm{ng} / \mathrm{mL}$ in winter and spring [27]. Therefore, the administration of VD supplements to Korean adolescents is needed for musculoskeletal me- tabolism as well as for boosting immunity [28].

Because VD supplements are inexpensive, it is considered, as a part of the LTBI screening project, to conduct community trials at the school level among students at high risk for LTBI to secure evidence for the efficacy of VD supplements [29]. If the budget for the related project and research is high, it may be considered to provide VD supplements to LTBI-positive students who refused anti-TB medication mainly in the winter and spring seasons when there is low sunlight. In particular, we suggest that VD be provided primarily to students with LTBI who refuse anti-TB medication. Subsequently, a randomized controlled study in the future is proposed to compare the conversion rate of active TB between those receiving $\mathrm{VD}$ supplements and those receiving anti-TB drugs.

\section{CONFLICT OF INTEREST}

The authors have no conflicts of interest to declare for this study.

\section{SUPPLEMENTARY MATERIALS}

Supplementary Material: Korean version is available at http:// www.e-epih.org/.

\section{ORCID}

Eun Hee Kim: http://orcid.org/0000-0002-1065-1080; Jong-Myon Bae: https://orcid.org/0000-0003-3080-7852

\section{REFERENCES}

1. Korea Centers for Disease Control and Prevention. Tuberculosis is progressing now [cited 2017 Mar 25]. Available from: http://cdc. go.kr/CDC/intro/CdcKrIntro0505.jsp? menuIds = HOME001MNU1154-MNU2557-MNU2487\&fid = 7947\&cid = $73871($ Korean).

2. Getahun H, Matteelli A, Abubakar I, Aziz MA, Baddeley A, Barreira D, et al. Management of latent Mycobacterium tuberculosis infection: WHO guidelines for low tuberculosis burden countries. Eur Respir J 2015;46:1563-1576. 
3. Bae JM. An opposing view on including high school students in a latent tuberculosis infection control program in Korea. Epidemiol Health 2017;39:e2017015.

4. Cho KS, Park WS, Jeong HR, Kim MJ, Park SJ, Park AY, et al. Prevalence of latent tuberculosis infection at congregated settings in the Republic of Korea, 2017. Public Health Wkly Rep 2018;11: 348-354 (Korean).

5. Aftertherain. Urgent suggestion for stopping the control program of latent tuberculosis infection in high school students: 2017 Mar 24 [cited 2018 Apr 25]. Available from: http://aftertherain.kr/?p= 34336 (Korean).

6. Trimble WS, Grinstein S. TB or not TB: calcium regulation in mycobacterial survival. Cell 2007;130:12-14.

7. Liu PT, Stenger S, Li H, Wenzel L, Tan BH, Krutzik SR, et al. Tolllike receptor triggering of a vitamin D-mediated human antimicrobial response. Science 2006;311:1770-1773.

8. Zittermann A, Pilz S, Hoffmann H, März W. Vitamin D and airway infections: a European perspective. Eur J Med Res 2016;21:14.

9. Kearns MD, Tangpricha V. The role of vitamin D in tuberculosis. J Clin Transl Endocrinol 2014;1:167-169.

10. Talat N, Perry S, Parsonnet J, Dawood G, Hussain R. Vitamin D deficiency and tuberculosis progression. Emerg Infect Dis 2010; 16:853-855.

11. McCullough PJ, Lehrer DS. Vitamin D, cod liver oil, sunshine, and phototherapy: safe, effective and forgotten tools for treating and curing tuberculosis infections - a comprehensive review. J Steroid Biochem Mol Biol 2018;177:21-29.

12. Balcells ME, García P, Tiznado C, Villarroel L, Scioscia N, Carvajal C, et al. Association of vitamin D deficiency, season of the year, and latent tuberculosis infection among household contacts. PLoS One 2017;12:e0175400.

13. Koh GC, Hawthorne G, Turner AM, Kunst H, Dedicoat M. Tuberculosis incidence correlates with sunshine: an ecological 28year time series study. PLoS One 2013;8:e57752.

14. Huang SJ, Wang XH, Liu ZD, Cao WL, Han Y, Ma AG, et al. Vitamin D deficiency and the risk of tuberculosis: a meta-analysis. Drug Des Devel Ther 2016;11:91-102.

15. Wallis RS, Zumla A. Vitamin D as adjunctive host-directed therapy in tuberculosis: a systematic review. Open Forum Infect Dis 2016;3:ofw151.

16. Keflie TS, Nölle N, Lambert C, Nohr D, Biesalski HK. Vitamin D deficiencies among tuberculosis patients in Africa: a systematic review. Nutrition 2015;31:1204-1212.

17. Zeng J, Wu G, Yang W, Gu X, Liang W, Yao Y,et al. A serum vitamin D level $<25 \mathrm{nmol} / \mathrm{l}$ pose high tuberculosis risk: a meta-analysis. PLoS One 2015;10:e0126014.

18. Sutaria N, Liu CT, Chen TC. Vitamin D status, receptor gene pol- ymorphisms, and supplementation on tuberculosis: a systematic review of case-control studies and randomized controlled trials. J Clin Transl Endocrinol 2014;1:151-160.

19. Nnoaham KE, Clarke A. Low serum vitamin D levels and tuberculosis: a systematic review and meta-analysis. Int J Epidemiol 2008;37:113-119.

20. Xia J, Shi L, Zhao L, Xu F. Impact of vitamin D supplementation on the outcome of tuberculosis treatment: a systematic review and meta-analysis of randomized controlled trials. Chin Med J (Engl) 2014;127:3127-3134.

21. Yamshchikov AV, Desai NS, Blumberg HM, Ziegler TR, Tangpricha V. Vitamin D for treatment and prevention of infectious diseases: a systematic review of randomized controlled trials. Endocr Pract 2009;15:438-449.

22. Gibney KB, MacGregor L, Leder K, Torresi J, Marshall C, Ebeling $\mathrm{PR}$, et al. Vitamin D deficiency is associated with tuberculosis and latent tuberculosis infection in immigrants from sub-Saharan Africa. Clin Infect Dis 2008;46:443-446.

23. Martineau AR, Wilkinson RJ, Wilkinson KA, Newton SM, Kampmann B, Hall BM, et al. A single dose of vitamin D enhances immunity to mycobacteria. Am J Respir Crit Care Med 2007;176: 208-213.

24. Ganmaa D, Giovannucci E, Bloom BR, Fawzi W, Burr W, Batbaatar D, et al. Vitamin D, tuberculin skin test conversion, and latent tuberculosis in Mongolian school-age children: a randomized, double-blind, placebo-controlled feasibility trial. Am J Clin Nutr 2012; 96:391-396.

25. Arnedo-Pena A, Juan-Cerdán JV, Romeu-García A, García-Ferrer D, Holguín-Gómez R, Iborra-Millet J, et al. Vitamin D status and incidence of tuberculosis among contacts of pulmonary tuberculosis patients. Int J Tuberc Lung Dis 2015;19:65-69.

26. Byun EJ, Heo J, Cho SH, Lee JD, Kim HS. Suboptimal vitamin D status in Korean adolescents: a nationwide study on its prevalence, risk factors including cotinine-verified smoking status and association with atopic dermatitis and asthma. BMJ Open 2017;7: e016409.

27. Lee YA, Kim HY, Hong H, Kim JY, Kwon HJ, Shin CH, et al. Risk factors for low vitamin D status in Korean adolescents: the Korea National Health and Nutrition Examination Survey (KNHANES) 2008-2009. Public Health Nutr 2014;17:764-771.

28. Hong JY, Kim SY, Chung KS, Kim EY, Jung JY, Park MS, et al. Association between vitamin D deficiency and tuberculosis in a Korean population. Int J Tuberc Lung Dis 2014;18:73-78.

29. Dini C, Bianchi A. The potential role of vitamin D for prevention and treatment of tuberculosis and infectious diseases. Ann Ist Super Sanita 2012;48:319-327. 